\title{
EFFICACY OF SELECTED CHEMOTHERAPEUTIC AND MEDICINAL PLANTS ON FUNGAL FISH PATHOGENS
}

\author{
T. Rahman, M. B. R. Chowdhury ${ }^{1}$ and M. A. R. Faruk ${ }^{1}$ \\ Department of Aquaculture, Sylhet Agricultural University, Sylhet-3100, Bangladesh
}

\begin{abstract}
Studies were conducted to examine the efficacy of selected chemotherapeutic and medicinal plants against common fungal fish pathogens. Four different doses of available fungicidal agents viz., lime + salt, brilliant green, malachite green and methylene blue were applied to the fresh culture of newly isolated fish pathogenic fungi (Aphanomyces invadans, Saprolegnia sp. and Achlya sp.) under in-vitro condition and minimum inhibitory dose (MID) was determined. Based on in-vitro results, chemotherapeutic were applied to the experimental infection of fish (Barbonymus gonionotus). Salt + lime, brilliant green and malachite green offered better results in reducing the rate of infection followed by medium effective methylene blue. Medicinal plants were selected on the basis of previous studies. Crude extracts were prepared from various parts (leaves and bulb) of neem (Azadirachta indica), turmeric (Curcuma longa) and shoti (C. zedoaria) and four different doses were applied to the fresh culture of above mentioned fungal pathogens under in-vitro condition to determine MID. Treatment trial was performed using the MID of the highly effective plant extracts (viz., tumeric, shoti, neem + tumeric and neem + shoti) on experimental infection of fish. Turmeric and neem + tumeric were found to be the most effective ones. Thus, medicinal plants would be an effective and alternative control measure along with selected chemotherapeutic against fungal diseases of fish.
\end{abstract}

Key words : Chemotherapeutic, Medicinal plants, Fungal fish pathogens

\section{INTRODUCTION}

Fish disease caused by fungal infection is common in both farmed and wild fishes throughout the world. Fungal disease in water bodies and fish culture system in Bangladesh has also been recognized as emerging disease problems in fish production (Habib et al., 2007). Fungi are primarily regarded as a secondary invader and known to attack the host when it gets injured either mechanically or as a result of infection other than fungal (Scott and O' Bier, 1962). The family Saprolegniaceae contains the majority of fungi that have been associated with disease in fish and shellfish such as Aphanomyces, Saprolegnia, Leptolegnia, Achlya, Dictyuchus (Srivastava, 1980). Three fish pathogenic fungi viz. Achlya sp., Saprolegnia sp. and Leptolegnia sp. have been reported to be isolated and identified (Zahura, 2001; Habib, 2002) other than A. invadans fungus (causative agent of Epizootic Ulcerative Syndrome) in Bangladesh.

\footnotetext{
${ }^{1}$ Department of Aquaculture, Bangladesh Agricultural University, Mymensingh-2202, Bangladesh
} 
Chemotherapeutic is mainly used in aquaculture for the treatment and prophylaxis of disease problems. An advantage of chemical application is that it achieves quick result (Tonguthai, 1996). Successful chemotherapy against fungal diseases has been reported using different treatments. The fungicides used are 'protectant' rather than 'systemic' and are applied to the water in which they are held rather than to the fish themselves (Willoughby and Roberts, 1994). In laboratory treatment trial, Scott and O' Warren (1964) recommended $2 \mathrm{ppm}$ concentrations of malachite green for complete destruction of fungal hyphae within $24-72 \mathrm{~h}$. treatment. Sati and Khulbe (1985) found $0.05 \%$ formalin treatment for 20 minutes was effective against some water molds. Roberts et al. (1992) showed that only very low concentrations $(0.25 \mathrm{ppm})$ of malachite green are required to kill Saprolegnia parasitica zoospores and cysts. Lime is suitable to control EUS through improving or disinfecting the water quality (Das and Das, 1993). The most effective treatment was observed in the combination of salt and lime against the infectivity of $A$. invadans; malachite green and methylene blue were effective against the Saprolegnia sp. and Achlya sp. (Islam, 2004).

Medicinal plants are part and parcel of human society to combat diseases, from the dawn of civilization (Biswas et al., 2002). Different types of medicinal plants are now using against fish disease in Asia but its application and research on the herbal therapy is still under experimental stages in Bangladesh. Kraus (1995) found that extract of neem fruit, seeds, seed kernel, twigs, stem bark and root have fungicidal and bactericidal properties. In Thailand, during the outbreak of EUS in 1983, the snake-head fish farmers used the bark of cork wood tree (Sesbania grandiflora) for the treatment of haemorrhage lesions (Direkbusarakom, 2000). Khan (2001) recommended for use of Neem as a preventive treatment for EUS in small ponds and also mentioned that neem treatment is less hazardous compared to other fungicidal treatments. Talukder (2005) observed that extracts of Azadirachta indica, Curcuma zedoaria and C. longa were inhibitory against the fungal growth. The inhibitory effect increased when $A$. indica was applied equally mixed with either C. zedoaria or C. longa.

Sporadic findings from the previous studies could not meet up a suitable prevention and control measure against fungal diseases of fish. Considering the importance, the present study was a fruitful initiative to develop suitable control measures by re-examining the scattered findings using low-cost chemotherapeutic and locally available medicinal plants.

\section{MATERIALS AND METHODS}

\section{Selection of pathogens}

Due to low virulent characters of laboratory stock pathogens, fresh isolates were collected from diseased (both EUS and non-EUS ulcerated fish) wild and farmed fishes for using in this study. Characterization, identification and pathogenicity of the fungal isolates were determined according to the techniques followed in previous studies (Zahura, 2001; Habib, 2002; Muniruzzaman, 2004). Newly isolated Aphanomyces invadans (TK-1), Saprolegnia sp. (Sap-4) and Achlya sp. (Ach-2) were detected as strong to moderate 
virulent based on their high pathogenic performance and selected for further studies. The whole experiment was carried out during the period from September 2006 to March 2007.

\section{Selection of Chemotherapeutic}

Based on preliminary investigation, availability in markets and reports of the previous workers, four different chemotherapeutic (Fig. 1) viz., lime + salt, brilliant green (BDH Chemicals, Poole, England), methylene blue (Loba Chemie PVT Ltd., Mumbai, India) and malachite green (Merck Ltd., Worli, Mumbai, India) were selected for this study with various doses.

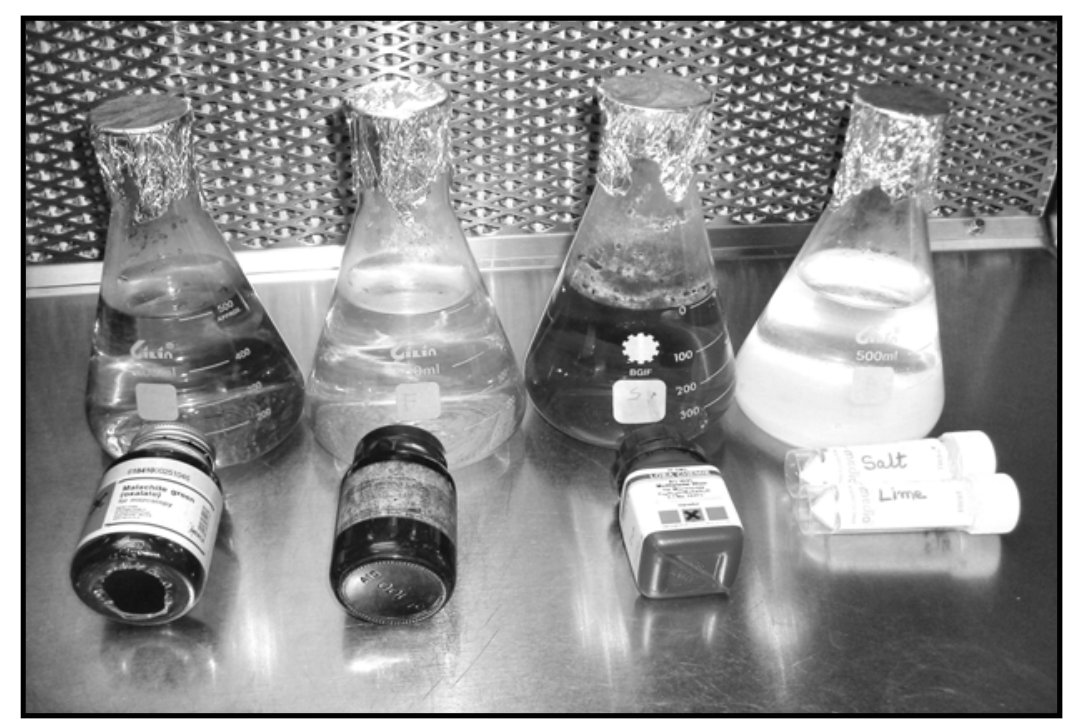

Fig. 1. Chemotherapeutic and their working solutions used against fungal fish pathogens

\section{Selection of medicinal plants and extracts preparation}

Fifteen medicinal plants were primarily selected based on their recognized medicinal properties described by Dastur (1977); Anawer (2001) and the previous studies conducted by Muniruzzaman and Chowdhury (2004); Talukdar (2005). Among these, most effective turmeric (Curcuma longa), shoti holud (C. zedoaria), and mixed extracts of neem + turmeric and neem + shoti were selected for the present studies. Most of the medicinal plants were collected from the adjacent area of Bangladesh Agricultural University, Mymensingh.

Desired parts of plants were washed with clean water, rinsed with sterilized distilled water and cut into small pieces. Before making crude extract, each medicinal plant was weighed and then paste was prepared using stone made homogenizer. Fibrous particulates from the extracts were screened out by pressing through fine meshed markin cloth and finally filtered through Whatman 541 filter paper to get fine extracts. Crude 
extracts were then collected in conical flasks and preserved into refrigerator at low temperature of $10^{\circ} \mathrm{C}$ (Fig. 2) for future use under the laboratory condition.

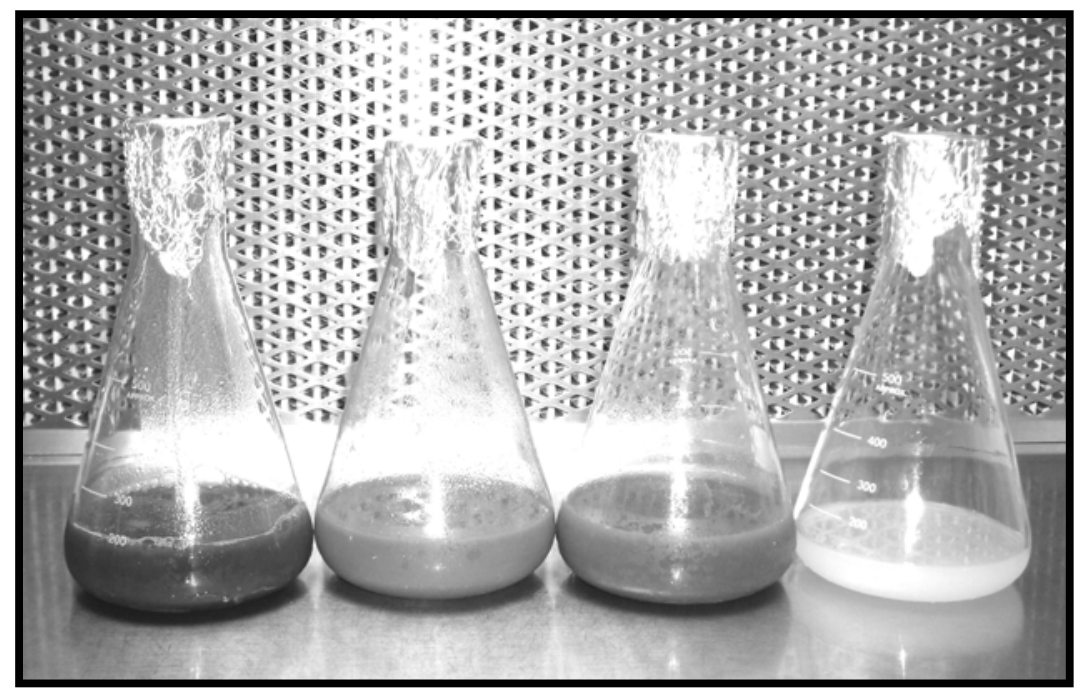

Fig. 2. Crude extracts of medicinal plants maintained at $10^{\circ} \mathrm{C}$

\section{In-vitro efficacy test}

In-vitro efficacy test of the fungicidal chemotherapeutic and medicinal plats against the above mentioned fish pathogenic fungi were carried out in separate vials (capacity 20 $\mathrm{ml}$ ), containing $10 \mathrm{ml} \mathrm{GP}$ broth. Subculture technique of fungal isolates was performed following the method described by Muniruzzaman (2004); Talukdar (2005). The fungi were sub-cultured aseptically on GP agar plates and incubated at $22^{\circ} \mathrm{C}$ for $18 \mathrm{~h}$. Pattern of fungal growth was observed daily up to 10 days of experimental periods.

For in-vitro test of chemotherapeutic, circular agar blocks (4 $\mathrm{mm}$ in diameter), containing fungal hyphae were cut by sterile Cork Borer and kept into individual vials containing 10 $\mathrm{ml} \mathrm{GP}$ broth and $1 \mathrm{ml}$ of each chemotherapeutic agent. Four different doses (Table 1) of fungicidal agents were used and minimum inhibitory dose (MID) was detected through the observation of inhibitory growth performances of fungus. Effective dose was determined when growth of fungal mycelium was fully stopped. The inactive fungal mycelium block further placed on GP-agar plate to assess the efficacy of chemotherapeutic. No fungal growth indicated the appropriate dose for each case.

For in-vitro test of medicinal plants, extracts of different doses (Table 2) were taken into vials containing $10 \mathrm{ml}$ GP broth and a fungal block and incubated at $22^{\circ} \mathrm{C}$. No extract was mixed in the case of control. Efficacy of mixed plant extracts was also tested by mixing the extract of $A$. indica together with $C$. zedoaria and C. longa at a ratio of 1:1. Treated 
hyphal blocks were then re-cultured to ensure their inhibition of growth. The MID of the effective plants tested was found to vary with different fungal species.

Table 1. Selected chemotherapeutic with their varied doses applied on fungal isolates

\begin{tabular}{|c|c|c|}
\hline Sl. No. & Name of fungicidal chemicals & Doses \\
\hline \multirow[t]{4}{*}{1.} & Salt +lime & $0.5 \%+10 \mathrm{ppm}$ \\
\hline & & $1.0 \%+15 \mathrm{ppm}$ \\
\hline & & $1.5 \%+20 \mathrm{ppm}$ \\
\hline & & $2.0 \%+25 \mathrm{ppm}$ \\
\hline \multirow[t]{4}{*}{2.} & Brilliant blue & $0.1 \mathrm{ppm}$ \\
\hline & & $0.2 \mathrm{ppm}$ \\
\hline & & $0.3 \mathrm{ppm}$ \\
\hline & & $0.4 \mathrm{ppm}$ \\
\hline \multirow[t]{4}{*}{3.} & Malachite green & $0.4 \mathrm{ppm}$ \\
\hline & & $0.6 \mathrm{ppm}$ \\
\hline & & $0.8 \mathrm{ppm}$ \\
\hline & & $1.0 \mathrm{ppm}$ \\
\hline \multirow[t]{4}{*}{4.} & Methylene blue & $2 \mathrm{ppm}$ \\
\hline & & $4 \mathrm{ppm}$ \\
\hline & & $6 \mathrm{ppm}$ \\
\hline & & $8 \mathrm{ppm}$ \\
\hline
\end{tabular}

Table 2. Various doses of selected medicinal plants applied on pathogenic fungal isolates

\begin{tabular}{|c|c|c|}
\hline Sl. No. & Name of medicinal plants & Doses \\
\hline 1. & Turmeric (bulb) & $\begin{array}{c}20 \mathrm{mg} / \mathrm{ml} \\
15 \mathrm{mg} / \mathrm{ml} \\
10 \mathrm{mg} / \mathrm{ml} \\
5 \mathrm{mg} / \mathrm{ml}\end{array}$ \\
\hline 2. & Shoti (bulb) & $\begin{array}{c}20 \mathrm{mg} / \mathrm{ml} \\
15 \mathrm{mg} / \mathrm{ml} \\
10 \mathrm{mg} / \mathrm{ml} \\
5 \mathrm{mg} / \mathrm{ml}\end{array}$ \\
\hline 3. & Neem (leaf) + Shoti (bulb) & $\begin{array}{c}20 \mathrm{mg} / \mathrm{ml} \\
15 \mathrm{mg} / \mathrm{ml} \\
10 \mathrm{mg} / \mathrm{ml} \\
5 \mathrm{mg} / \mathrm{ml}\end{array}$ \\
\hline 4 . & Neem (leaf) + Turmeric (bulb) & $\begin{array}{c}20 \mathrm{mg} / \mathrm{ml} \\
15 \mathrm{mg} / \mathrm{ml} \\
10 \mathrm{mg} / \mathrm{ml} \\
5 \mathrm{mg} / \mathrm{ml}\end{array}$ \\
\hline
\end{tabular}




\section{Investigation on the therapeutic effects (In-vivo) Preparation of zoospore suspension and abrasion of fish}

Zoospore suspension of the pathogenic fungal isolates was prepared as described by Willoughby and Roberts (1994); Lilley (1997). These zoospores were used for experimental infection.

Disease free young Thai silver barb (Barbonymus gonionotus), weighing 15 to 20 gm were abraded on 3-4 $\mathrm{mm}^{2}$ area by removing patches of scales from each side of the body below the dorsal fin. Each group of fish (10 fish per 15 litre of water) was exposed to zoospore suspension of ( $30 \mathrm{ml}$ autoclave pond water, APW containing zoospore/1 litre tap water.) A. invadans, Saprolegnia sp. and Achlya sp. separately under aerated condition in a 30-litre capacity glass aquarium. Controlled fishes were released into the aquarium having only APW and no zoospore. After few days, the fungal infection was observed in the reddening and raised ulcerated form (Fig. 3) on the abraded part (base of scales) of the experimental fish. Clinical signs of infection, moribundness, death of fish and recovery of disease (Fig. 4) were recorded for each aquarium.

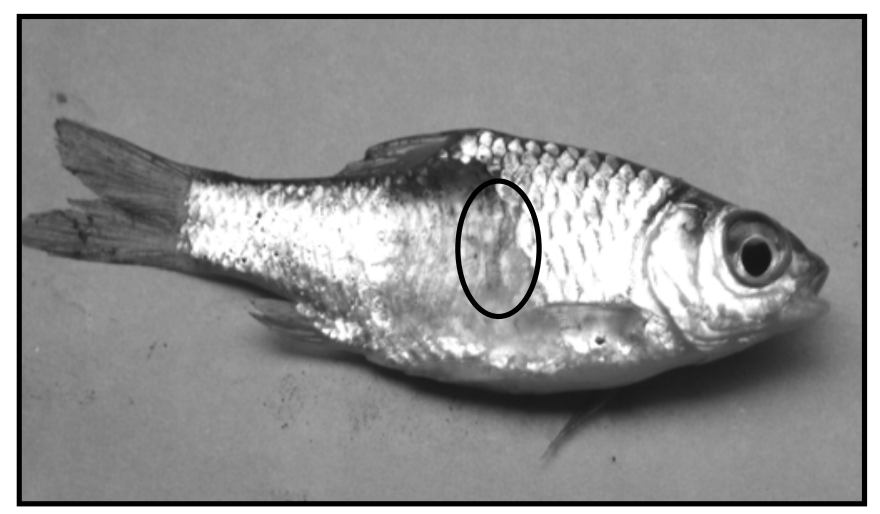

Fig. 3. Dermal lesion in Thai silver barb challenged with Aphanomyces sp. (TK-1) at abraded condition

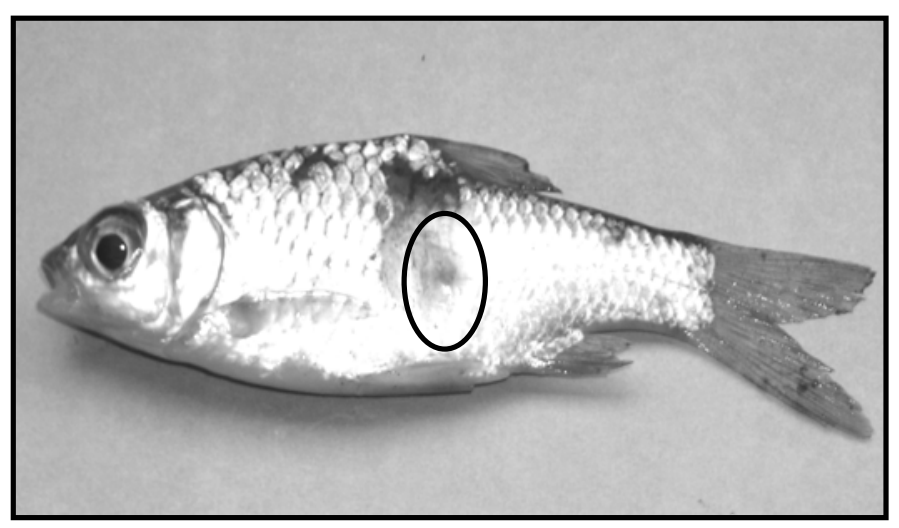

Fig. 4. Recovery of challenged fish after 10 days treatment under laboratory condition 


\section{Chemotherapeutic effects on the infectivity of fungi}

After releasing motile zoospores in each aquarium, the infection was observed within few days. The exposed fish were transferred to other aquaria for chemotherapy. The treatments selected for this purpose were $T_{1}$ with salt + lime, $T_{2}$ with brilliant green, $T_{3}$ with methylene blue, $T_{4}$ with malachite green and $T_{5}$ as control. Short bath treatment was applied separately in individual chemotherapeutic for about 30 minutes and twice per day. Temperature was maintained by room temperature and dissolved oxygen was ensured by regular aeration. Chemotherapeutic trial was continued up to 10 days with the same dosage.

\section{Therapeutic effects of medicinal plants}

Extracts of turmeric, shoti, and two mixed extracts of neem + shoti and neem + turmeric were used for treatment trials $\left(T_{1}, T_{2}, T_{3}\right.$ and $T_{4}$ respectively) whereas control $\left(T_{5}\right)$ received no plant extract. Dip bath treatment was applied to observe their therapeutic effects. Whole process was performed according to studies conducted by Muniruzzaman (2004); Talukdar (2005). Clinical signs was observed and recorded daily. After 10 days of experimental period, fish muscle from the abraded location was aseptically removed, placed on GP agar and incubated at $25^{\circ} \mathrm{C}$ to check fungal growth. Three replications were taken for each test.

The analysis of data was done following one way analysis of variance (ANOVA) using MSTAT programme. The mean differences among the treatments were adjudged with Duncan's Multiple Range Test (Gomez and Gomez, 1984).

\section{RESULTS AND DISCUSSION}

The present study was designed to examine the medicinal efficacies of some selected chemotherapeutic and available medicinal plants against fungal fish pathogens causing diseases in cultured fishes. Growth of fungus was found to be affected by different doses of various chemotherapeutic under In-vitro condition. Brilliant green (MID $0.3 \mathrm{ppm}$ ) was effective against all the three fungal isolates (Table 3). Salt + lime and malachite green (MID 2.0\% $+25 \mathrm{ppm}$ and $0.8 \mathrm{ppm}$, respectively) showed better performances against fungal isolates than that of methylene blue (MID 6 ppm).

Chowdhury et al. (2003) observed that salt and lime combinedly showed suppressive effect on the growth of Aphanomyces in GP broth under laboratory condition. Scott and $\mathrm{O}^{\prime}$ Warren (1964) used $2 \mathrm{ppm}$ of malachite green for complete destruction of fungal hyphae within 24-72 h treatment. Roberts et al. (1992) found that $0.25 \mathrm{ppm}$ of malachite green was required to kill S. parasitica. Although Borghetti, et al. (1994) found no significant differences among mortality rates after evaluating the efficiency of different treatments ( $66.7 \mathrm{mg} / 1$ of malachite green; $10 \mathrm{~g} / 1$ of salt $(\mathrm{NaCl})$ and $3 \mathrm{mg} / 1$ of methylene blue).

Effects of different chemotherapeutic on the experimental infection of fish with fungal pathogens under laboratory condition provided useful information in treatment of fugal fish diseases. Suspension of salt + lime together $\left(T_{1}\right)$ was found to be significantly 
$(\mathrm{p}<0.05)$ effective $(80 \pm 2.88 \%$ recovery rate) one in reducing the A. invadans, Saprolegnia and Achlya infection in fish. Such result was similar to the findings of (Alam, 2004). Brilliant green $\left(\mathrm{T}_{2}\right)$ also performed a good fungicidal action with $80.00 \pm 2.31 \%$ recovery rates. Application of malachite $\left(\mathrm{T}_{4}\right)$ green was effective $(80.00 \pm 1.15 \%$ recovery rate) in reducing the Saprolegnia and Achlya infection but very weak against A. invadans infection. This result was directly correlated with Muniruzzaman (2004); Alam (2004). However, present study resulted that methylene blue $\left(\mathrm{T}_{3}\right)$ was medium effective with fewer $(70.00 \pm$ $1.73 \%$ ) recovery rate; which ultimately differed with previous studies. Therapeutic effects of the tested chemotherapeutic were shown in Table 4 and its graphical presentation was illustrated in Fig. 5.

Table 4. Statistical analysis of the effect of chemicals on experimentally infected fish with fungal pathogens

\begin{tabular}{lcc}
\hline \multicolumn{1}{c|}{ Treatment } & Dose $(\mathrm{mg} / \mathrm{l})$ & Recovery $(\%)$ \\
\hline $\mathrm{T}_{1}:$ Salt + lime & $2.0 \%+25 \mathrm{ppm}$ & $80.00^{\mathrm{b}} \pm 2.89$ \\
$\mathrm{~T}_{2}:$ Brilliant green & $0.3 \mathrm{ppm}$ & $80.00^{\mathrm{b}} \pm 2.31$ \\
$\mathrm{~T}_{3}:$ Methylene Blue & $6 \mathrm{ppm}$ & $70.00^{\mathrm{c}} \pm 1.73$ \\
$\mathrm{~T}_{4}:$ Malachite Green & $0.8 \mathrm{ppm}$ & $80.00^{\mathrm{b}} \pm 1.15$ \\
$\mathrm{~T}_{5}:$ Control & No dose & $0 \mathrm{~g}$ \\
Level of significant & & $* *$ \\
\hline
\end{tabular}

Values bearing different superscripts $(a, b, c, d, e, f, g)$ in the same column are significantly different but with the same superscripts are not significantly different $(\mathrm{p}<0.05)$

** : Significant $(p<0.05)$; Recovery $(\%)$ : Mean \pm S.E

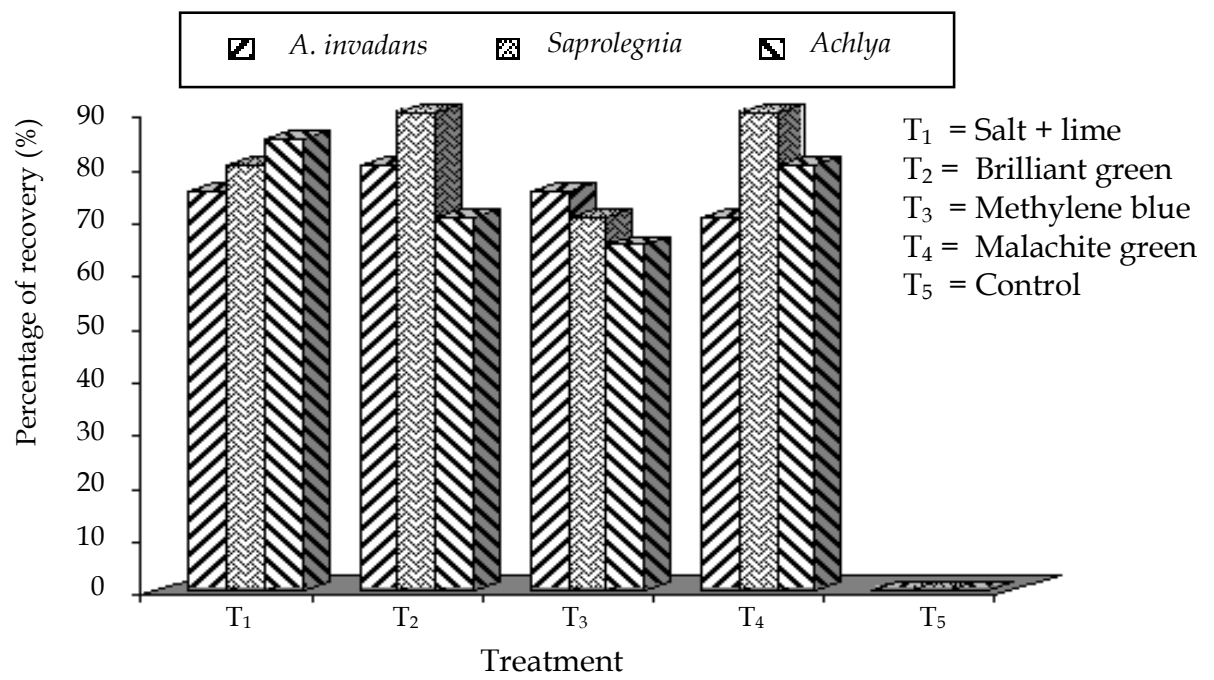

Fig. 5. Different chemotherapeutic effects on the experimental infection of fish with fungal pathogens 
In the case of medicinal plants, four pre-selected doses of shoti, turmeric, mixed extracts of neem + shoti and neem + turmeric were selected for in-vitro study. Bulb extracts of turmeric showed best inhibitory response against all the fungi tested whereas bulb extracts of shoti exhibited as medium effective at the same dose. In the case of mixed plants extracts, inhibitory effect increased when neem was applied equally mixing with shoti and turmeric. The MID in this respect were found to vary with the plant species and fungal pathogens tested. Higher inhibitory effect of turmeric and shoti was recorded when MID was $20 \mathrm{mg} / \mathrm{ml}$ (Table 3). In mixed cases, both neem (leaf) + shoti (bulb) and neem (leaf) + turmeric (bulb) were found to be low effective at $10 \mathrm{mg} / \mathrm{ml}$ but fungal growth were fully stopped at MID $15 \mathrm{mg} / \mathrm{ml}$ against the plants tested.

Among four different treatments, a successful therapeutic effect against pathogenic fungal infection was found from $\mathrm{T}_{1}$, where extract of turmeric recovered $80.00 \% \pm 1.15$ of challenged fish (Table 5). Similar fungicidal performance was also observed when neem was mixed with either turmeric $\left(\mathrm{T}_{3}\right)$ or shoti $\left(\mathrm{T}_{4}\right)$ with good recovery rates of $80.00 \% \pm$ 2.88 and $70.00 \% \pm 2.88$ respectively. Such findings were similar to the previous studies (Muniruzzaman, 2004; Talukdar, 2005). Moreover, shoti $\left(T_{2}\right)$ also performed as medium effective plant in reducing fungal infection and the rate of recovery was recorded up to $60 \%$. Graphical presentation of therapeutic effects was shown in Fig. 6.

Table 5. The effect of medicinal plants on experimentally infected fish with fungal pathogens

\begin{tabular}{lcc}
\hline \multicolumn{1}{c|}{ Treatment } & Dose $(\mathrm{mg} / \mathrm{ml})$ & Recovery $(\%)$ \\
\hline $\mathrm{T}_{1}:$ Turmeric (C. longa) & 20 & $80.00^{\mathrm{a}} \pm 1.15$ \\
$\mathrm{~T}_{2}$ : Shoti (C. zedoaria) & 20 & $60.00^{\mathrm{c}} \pm 5.77$ \\
$\mathrm{~T}_{3}:$ Neem + Shoti (A. indica + C. zedoaria) & 15 & $70.00^{\mathrm{b}} \pm 3.33$ \\
$\mathrm{~T}_{4}:$ Neem + Turmeric (A. indica + C. longa) & 15 & $80.00^{\mathrm{a}} \pm 2.89$ \\
$\mathrm{~T}_{5}:$ Control & No extract & $0^{\mathrm{h}}$ \\
Level of significant & & $* *$ \\
\hline
\end{tabular}

Values bearing different superscripts $(a, b, c, d, e, f, g, h)$ in the same column are significantly different but with the same superscripts are not significantly different $(\mathrm{p}<0.05)$

** : Significant $(\mathrm{p}<0.05)$; Recovery $(\%)$ : Mean \pm S.E.

The essential oil fractions from $C$. longa rhizomes of various habitats exhibited fungistatic activity particularly against Aspergillus niger and Physalospora tucumanesis, Ceratocystis paradora, Sclerotium solfsii, Curoularis lunata, Helminthosporium sacchari, Fusarium moniliforms and Cephalosporium sacchari (Khanna, 1999). In the in-vitro trial, Campbell et al. (2001) found that neem extracts as well as malachite green, ash, potassium permanganate had a strong antifungal property against $A$. invadans. Anon, (1994) suggested that a paste prepared from ground neem (A. indica) leaves and tumeric were effective against EUS by inhibiting the spread of infection as well as influencing the growth and survival of recovered fish. Thus, medicinal plants can be used as an effective control measure along with chemotherapeutic against fungal diseases of fish. 
114 Efficacy chemotherapeutic and medicinal plants on fungal fish pathogens

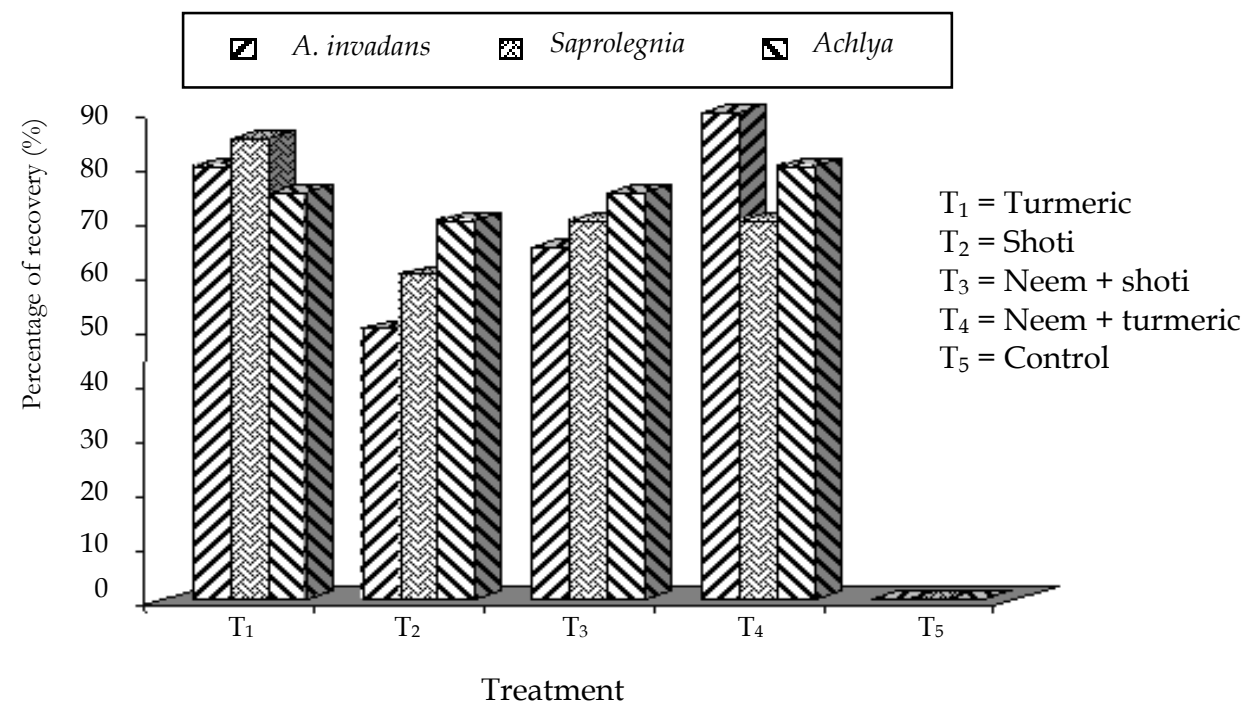

Fig. 6. Therapeutic effects of different medicinal experimental infection of fish with plants on the fungal pathogens

Further detailed studies are necessary regarding their application at field level to establish the facts.

\section{REFERENCES}

Alam, M. S. 2004. Efficacy of different chemotherapeutics against the growth and infectivity of three fish pathogenic fungi. M. S. Thesis, Department of Aquaculture, Bangladesh Agricultural University, Mymensingh. 65 pp.

Anawer, M. (ed.). 2001. Vesoj Udvider Homeophathic Baboher: Bangladesh Prakhit (Homeopathic uses of medicinal plants; Bangladesh perspective). Published by text book division, Bangla Academy, Dhaka-1000, Bangladesh. 545 pp.

Anon. 1994. Indigenous treatment for fish disease. The Hindu, 9 November 1994.

Biswas, K., Chattopadhyay, I., Banerjee, R. K. and Bandyopadhyay, U. 2002. Biological activities and medicinal properties of neem (Azadirachta indica), Curr. Sci., 82(11): 1336-1345.

Borghetti, N. R. B., Canzi, C. and Dos-Santos, L. C. 1994. Efficiency of three different treatments in the fight of Saprolegniasis in juvenile pacu (Piaractus mesopotamicus). Rev. Unimar., 16(2): 275-280.

Campbell, R. E., Lilley, J. H., Taukhid, Panyawachirab, V. and Kanchanakhan, S. 2001. In vitro screening of novel treatments for Aphanomyces invadans. Aquacult. Res., 32: 1-11.

Chowdhury, M. B. R., Muniruzzaman, M., Zahura, U. A., Habib, K. Z. and Khatun, M. D. 2003. Ulcer type of disease in the fishes of small-scale farmer's pond in Bangladesh. Pakistan J. Biol. Sci., 6(6): 544-550. 
Das, M. K. and Das, R. K. 1993. A review of the fish disease epizootic ulcerative syndrome in India. Environ. Ecol., 11(1): 134-145.

Dastur, J. F. (ed.). 1977. Medicinal plants of India and Pakistan. Published by D.B. Taraporevala Sons \& Co. Private Ltd., 210, Dr. Dadabhai Naorojii Road, Bombay 400 001, 201pp.

Direkbusarakom, S. 2000. Application of herbs in aquaculture in Asia. AAHRI Newsletter, 9(2): 3-5.

Gomez, K. A. and Gomez, A. A. 1984. Statistical Procedure for Agricultural research. Int. Rice Res. Inst. John Wiley and Sons, New York, Chickester, Brisbane, Toronto, Singapore, pp. 139-240.

Habib, K. A. 2002. Recovery of associated fungi from diseased fishes, their pathogenicity and growth performance under different condition. M. S. Thesis, Department of Aquaculture, Bangladesh Agricultural University, Mymensingh. 100 pp.

Habib, K. A., Chowdhury, M. B. R. and Faruk, M. A. R. 2007. Recovery of fish pathogenic fungi from diseased fishes. Progress. Agric. 18(1): 147-154.

Islam, M. S. 2004. Effects of some chemotherapeutics on three major bacterial fish pathogens. M. S. Thesis, Department of Aquaculture, Bangladesh Agricultural University, Mymensingh. 69 pp.

Khan, M. H. 2001. Epidemiological studies on epizootic ulcerative syndrome (EUS) in Bangladesh. A Ph. D. Thesis, Institute of Aquaculture, University of Stirling, Scotland, UK, 250 pp.

Khanna, N. K. 1999. Turmaric Nature's precious gift. Curr. Sci., 76 (10) : 1351-1356.

Kraus, W. 1995. Azadirachtin and other triterpenoids, Biologically Active Ingredients In: Schmutterer, H. (ed.). The Neem Trees, VCH Publishers Inc., New York, USA. Chapter 2, pp. 35-73.

Lilley, J. H. 1997. Studies on the comperative biology of Aphanomyces invadans. A Ph. D. Thesis, University of Stirling, Scotland. 228 pp.

Muniruzzaman, M. 2004. Etiopathology and control measures of ulcer diseases in the cultured fishes of Bangladesh. A Ph. D. Thesis, Department of Aquaculture, Bangladesh Agricultural University, Mymensingh, Bangladesh. 302 pp.

Muniruzzaman, M. and Chowdhury, M. B. R. 2004. Sensitivity of fish pathogenic bacterial to various medicinal herbs. Bangladesh J. Vet. Med., 2(1): 75-82.

Rahman, M. M. 2005. Efficacy of medicinal plants against bacterial fish pathogens. M. S. Thesis, Department of Aquaculture, Bangladesh Agricultural University, Mymensingh, Bangladesh. 73 pp.

Roberts, R. J., Frerichs, G. N. and Millar, S. D. 1992. Epizootic ulcerative syndrome the current position. In: Shariff, M., R. P. Subasinghe and J. R. Arthur (eds.). Disease in Asian Aquaculture I. Fish Health Section, Asian Fisheries Society, Manila. pp. 431-436.

Sati, S. C. and Khulbe, R. D. 1985. A host range of Saprolegnia diclina Humphrey on certain cold water fishes of India. Proc. Nat. Acad. Sci. India, 53(8): 309-312.

Scott, W. W. and O'Bier, A. H. 1962. Aquatic fungi associated with diseased fish and fish eggs. Prog. Fish Cult., 24: 3 -15.

Scott, W. W. and O'Warren, C. 1964. Studies of the host range and chemical control of fungi associated with diseased tropical fish. Bull. Agric. Exp. Sta., 171: 1-24. 
116 Efficacy chemotherapeutic and medicinal plants on fungal fish pathogens

Srivastava, R. C. 1980. Chemotherapeutical studies on fish mycoses. Mh. Vet. Med., 35(7): 267-269.

Talukder, M. R. H. 2005. Native medicinal plants against fungal fish pathogens. M. S. Thesis, Department of Aquaculture, Bangladesh Agricultural University, Mymensingh, Bangladesh. 71 pp.

Tonguthai, K. 1996. The use of chemical in Aquaculture in Thailand. pp. 208-220. In: Meeting on the use of chemicals in Aquaculture in Asia. 20-22 May 1996, T. gbauan, lloilo, Philippines.

Willoughby, L. G. and Roberts, R. J. 1994. Improved methodology for isolation of the Aphanomyces fungal pathogen of epizootic ulcerative syndrome (EUS) in Asian fish. J. Fish Dis., 17: 541-543.

Zahura, U. A. 2001. Fungal infection in freshwater fishes in Mymensingh area. M. S. Thesis, Department of Aquaculture, Bangladesh Agricultural University, Mymensingh. $88 \mathrm{pp}$. 